\title{
The National Advisory Committee on Immunization (NACI): A celebration of fifty years of service
}

\author{
${ }^{1} \mathrm{NACl}$ Chair, Kingston ON \\ * Corresponding author: naci-ccni@phac-aspc.gc.ca
}

Gemmill I ${ }^{1 *}$

\section{Abstract}

The National Advisory Committee on Immunization (NACl) celebrates its fiftieth anniversary in October 2014. This paper outlines the history of $\mathrm{NACl}$ and its activities over the past 50 years. After its formation in 1964, NACI undertook the development of guidance for the few vaccines that were approved at that time, including polio, measles, tetanus, pertussis, diphtheria and smallpox. Although the Committee has evolved over the years, its focus has remained on providing guidance on an ever-increasing number of products: twenty-four, according to the recent updates to the Canadian Immunization Guide.

With the changing vaccine landscape, including immunization programs and practices, the membership of the Committee has evolved to include expanded expertise, such as immunology. The work of the Committee has had to adapt, with more complex and extensive evidence and the establishment of a published evidence-based methodology. Over the past 50 years, the success and accomplishments of NACI have been in large part due to the efforts of its chair and members, who have dedicated countless hours of work to committee activities and products. NACl's Technical advisory groups are recognized globally as a valuable resource, benefiting immunization practices and programs across Canada and internationally. $\mathrm{NACl}$ is a committee of which $\mathrm{PHAC}$ and indeed Canada can be truly proud.

\section{Introduction}

The National Advisory Committee on Immunization (NACl) will celebrate its fiftieth anniversary in October of 2014. This paper provides an account of NACl's formation, history and work over the past 50 years. The Committee was constituted in 1964 as the National Advisory Committee on Immunizing Agents by the then Department of National Health and Welfare and reported to the federal, provincial, territorial Dominion Council of Health. Over the last fifty years, $\mathrm{NACl}$ has provided evidence-based advice on vaccines authorized for use in Canada as well as immunization practices and schedules, through meticulous and pain-staking review and invoking the best judgement of some of the most knowledgeable professionals in paediatrics, nursing, infectious disease, immunology and public health in Canada. $\mathrm{NACl}$ has been a model for other policy and expert advisory committees in Canada and is highly regarded as the authority on immunization practice in this country.

\section{Early beginnings}

$\mathrm{NACl}$ held its first meeting in October of 1964 and was chaired by the highly respected Canadian virologist, Dr. Andrew Rhodes of the University of Toronto. A technical group had been convened to discuss the implementation of the polio vaccine in Canada several years earlier and it was Dr. Rhodes' vision that there was a need for a group to provide ongoing advice regarding polio and other new vaccines of the era, such as the measles vaccine. A presentation was made to the Dominion Council of Health (the group of Deputy Ministers that guided health programs in Canada) in April, 1963 and the constitution of a committee "in the capacity of an Advisory Committee on Vaccines" was approved. In 1977, the name was changed to the National Advisory Committee on Immunization (NACl), which reflected the fact that the Committee made recommendations on vaccines as well as immunization practices and programs. 
"The purpose of the Committee was [is] two-fold: first, to advise and to make recommendations on immunizing agents to the Minister through the Dominion Council of Health, as requested by Council or its Chairman; and second, to propose to Council aspects of immunizing agents that appear to warrant special consideration..." While the terms of reference of $\mathrm{NACl}$ have been updated on many occasions over the years, these two purposes still reflect the spirit of the Committee's fundamental work.

Dr. Rhodes' vision was clearly astute. In 1964, there were only a handful of vaccines. Smallpox vaccine had been used for decades, pertussis vaccine since 1918, diphtheria vaccine since the 1920s and tetanus vaccine since the 1940s (1). Polio and measles vaccines were new. Today, the online edition of the Canadian Immunization Guide (2) provides guidance on twenty-four vaccines and many more are anticipated. In addition, from time to time, $\mathrm{NACl}$ provides advice on the establishment of universal programs, such as hepatitis B vaccine for children and has provided guidance on best practice in immunization, from how to do a proper intramuscular (IM) injection, to communicating effectively to vaccine recipients. Further, in the future, NACl may be asked to provide guidance on other elements such as the cost-effectiveness of various vaccine programs. The scope of the work of NACI has expanded hugely over the last fifty years and it is difficult to imagine how health professionals and those responsible for implementing vaccines programs would manage without its guidance. The health system is fortunate to have an eminent body like $\mathrm{NACl}$ to provide unbiased and comprehensive advice on immunization.

\section{$\mathrm{NACl}$ members and leadership}

The membership of $\mathrm{NACl}$ has evolved over the years. Original members were leading names in virology, bacteriology and paediatrics, along with both federal and provincial public health administrators. In 1980, a local public health practitioner was added. Experts in infectious diseases were invited to join and an immunologist was recommended as early as 1976 ( $\mathrm{NACl}$ now has an immunologist as a standing member). Starting in the 1970s, various professional organizations involved in immunization practice were invited to appoint liaison representatives, who not only provide a link to those other organizations but also bring a wealth of knowledge and experience to the proceedings of $\mathrm{NACl}$. Some examples of these professional organizations are listed in Table 1.

Table 1: Liaison organizations represented on $\mathrm{NACl}$ over the past several decades

\begin{tabular}{l} 
- Advisory Committee on Epidemiology \\
- Advisory Committee on Immunization Practices, Centers for Disease Control and Prevention, \\
- Canociation of Medical Microbiology and Infectious Disease Canada \\
- Canadian Immunization Committee \\
- Canadian Infectious Disease Society \\
- Canadian Medical Association \\
- Canadian Nursing Coalition for Immunization \\
- Canadian Public Health Association \\
- Comection of Familional Health Nurses Association \\
- Council of Chief Medical Officers of Health \\
- Cociety of Obstetricians and Gynaecologists of Canada \\
\hline
\end{tabular}

$\mathrm{NACl}$ has been led by a series of distinguished health professionals who have served as its chair and who provided visionary leadership to NACl's work and discussions (Table 2). Sadly, the longest-serving chair, Dr. 
Michael Dixon, passed away in November 2013, less than one year before NACl's fiftieth anniversary. Dr. Dixon served as chair for seventeen years, 1972-1989.

Table 2: Chairs of the National Advisory Committee on Immunization

\begin{tabular}{|ll|}
\hline $1964-1966$ & Dr. Andrew Rhodes, Toronto, ON \\
$1968-1969$ & Dr. Edward Bynoe, Ottawa, ON (acting) \\
$1972-1989$ & Dr. J. Michael S. Dixon, Edmonton, AB \\
$1989-1993$ & Dr. Susan Tamblyn, Stratford, BC \\
$1993-1998$ & Dr. David Scheifele, Vancouver, BC \\
$1998-2003$ & Dr. Victor Marchessault, Ottawa ON (passed away March 31, 2003) \\
$2003-2007$ & Dr. Monika Naus, Vancouver, BC \\
$2008-2011$ & Dr. Joanne Langley, Halifax, NS \\
$2011-2014$ & Dr. Bryna Warshawsky, London, ON \\
$2014-$ & Dr. lan Gemmill, Kingston, ON \\
\hline
\end{tabular}

\section{The work of $\mathrm{NACl}$}

NACl's work has primarily focused on publishing guidance on vaccines and immunization practice through both statements on new vaccines or new indications for established vaccines and its main reference for the use of vaccines in Canada, the Canadian Immunization Guide. Statements on vaccines are needed whenever a new vaccine is authorized for use to support decision-making with credible, evidence-based guidance. NACl's statements have addressed this need since its inception in 1964. Statements are developed by first conducting an exhaustive review of the literature and then by writing guidance based on the best evidence, using a standard format (3).

Formerly, statements were written by individual members, but more recently, as the complexity of immunizing products has increased and the proliferation of similar products to protect against the same illnesses has occurred, working groups have been established to provide a broader mechanism to address this complex task. It is important to understand that recommendations of $\mathrm{NACl}$ are not based simply on product monographs, but all evidence that is available on a given vaccine. With the increasing complexity of immunizing products, there has also been a similar increase in the volume and complexity of epidemiological and clinical data that NACl assesses and grades to formulate its recommendations. Statements are thoroughly debated and thoughtfully crafted. In addition, readers of statements benefit from the good judgement of the members, who consider feasibility, practicability and a clear focus on what constitutes the best practice for recipients of vaccines. Once the lead author and the working group have agreed on the most reasonable, evidenced-based recommendations, the statement is discussed by all members of $\mathrm{NACl}$ for final approval. Over the years, statements have been made on new vaccines, on new developments in the literature about various vaccines and on vaccine-related issues, such as thimerosal.

The Canadian Immunization Guide (CIG) was first published in 1979 as the Guide to Immunization for Canadians, and has been revised every four years on average. The guide provided "comment and advice on the usage of all licensed immunizing agents for infectious diseases available in Canada at the time of writing" (4). The Committee believed "that this booklet would [will] help in the attainment of a greater degree of uniformity of immunization policy and practice in Canada than has been achieved in the past". The first edition was 92 pages in English version and 104 pages in French. The seventh edition, published in 2006, was almost 400 pages in length, and provides advice not only on specific vaccines, but on issues ranging from the use of various vaccines in special populations, to vaccine safety. With the increasing complexity of the practice of immunization and the fast rate of 
change in knowledge and with the advances in technology that facilitated an electronic version of the CIG, NACI undertook to develop an online edition which is easily edited and updated. The work on the online edition was completed in early 2014 and schedules for both ad hoc changes, precipitated by changes in knowledge and routine reviews over a cycle of four years are being developed.

\section{Conclusion}

$\mathrm{NACl}$ has been an institution in vaccinology in Canada for half a century. It has provided reliable and forwardthinking advice that goes beyond the legal requirements of a product monograph. It has outlived the Council that created it. It has been a resource to the Public Health Agency of Canada (PHAC) and its predecessors longer than most committees and it continues to thrive. The professionals who have served on NACI have contributed countless hours to ensure that Canadian health professionals have the best possible advice on immunization practice, and consider their appointment to this distinguished committee an honour. In fact, it is considered one of the premier committees in the health system in Canada and it has set the standard for providing evidence-based guidance.

The need and role for such technical advisory committees is recognized at a global level. Without the guidance of $\mathrm{NACl}$ over the years, the immunization system in Canada would likely be more chaotic and far less harmonized than it is. The World Health Organization recommends the establishment, support and strengthening of national advisory committees on immunization as a key element to improving immunization programmes and establishing priorities and introducing new vaccines and immunization technologies (5). On the fiftieth anniversary of $\mathrm{NACl}$, it is time to celebrate its contributions over the last half century and to thank the many professionals who have given their time and thoughtful attention to issues on immunization on behalf of us all and all of the committed people at PHAC and its predecessors who have supported NACl. It is a committee of which PHAC and indeed Canada can be truly proud.

\section{Acknowledgements}

The author would like to acknowledge previous work completed by Dr. Andrew Sherrington on the history of $\mathrm{NACl}$, which was widely used to write this commentary.

\section{References}

(1) Canadian Public Health Association. Immunization Timeline. http://www.cpha.ca/en/programs/history/achievements/12v/timeline.aspx.

(2) Public Health Agency of Canada. Canadian immunization guide. Ottawa: Public Health Agency of Canada. http://www.phac-aspc.gc.ca/publicat/cig-gci/index-eng.php.

(3) National Advisory Committee on Immunization. Evidence-based recommendations for immunization - Methods of the National Advisory Committee on Immunization. CCDR. January 2009;35(ASC-1).

(4) Health and Welfare Canada. A guide to immunization for Canadians. Ottawa: Supply and Services Canada; 1980.

(5) National Immunization Technical Advisory Groups (NITAGs): Guidance for their establishment and strengthening. Duclos P. Vaccine. 2010; 28(Supplement 1);A18-25. 